\title{
The Spatial Distribution of Root System in M9 Rootstock Is Affected by Apple Cultivar and Tree Age
}

\author{
Fadil Thomaj
}

Faculty of Agriculture and Environment, Agriculture University of Tirana, Tirana, Albania

E-mail: fadil_thomaj@hotmail.com

\author{
Hafuz Domi \\ ADAD, Tirana, Albania \\ E-mail: domihafuz@yahoo.com
}

\begin{abstract}
Glenda Sallaku
Faculty of Agriculture and Environment, Agriculture University of Tirana, Tirana, Albania E-mail: gsallaku@ubt.edu.al
\end{abstract}

Astrit Balliu (Corresponding author)

Faculty of Agriculture and Environment, Agriculture University of Tirana, Tirana, Albania

E-mail: aballiu@ubt.edu.al

Received: Sep. 11, 2019

doi:10.5296/jas.v7i4.15482
Accepted: Sep. 18, 2019 Published: Sep. 19, 2019

URL: https://doi.org/10.5296/jas.v7i4.15482

\begin{abstract}
The aim of study was to evaluate how different apple cultivars affect root morphology and spatial distribution of rootstock. The experiment was conducted with three different cultivars; 'Golden delicious', 'Gala' and 'Starking' grafted on M9 dwarfing rootstock. Nine and fourteen years old, French vertical axe trained trees were included in the experiment. The trench profile method was chosen to study the morphology of root system and the counted root intersects were divided into three classes; fine roots $(<2 \mathrm{~mm})$, medium-sized roots $(2-5$ $\mathrm{mm})$, and coarse roots $(>5 \mathrm{~mm})$. To analyze the spatial distribution of root system, the
\end{abstract}


respective cumulative number of fine roots at three successive distances from the base of tree trunk and the cumulative number of fine roots in three successive distances from soil surface were expressed as percentage versus the total fine roots. Significant effects of scion on the total number of fine roots, and as well, on their side and in depth distribution were found. The pattern of root distribution is changing over years, tending to shift the bulk of absorptive roots further from the tank and deeper into the soil. This tendency was more visible to high yielding and late maturity cultivars.

Keywords: grafting, scion, rootstock, root morphology, fine roots, spatial distribution

\section{Introduction}

Apple orchards are a major agricultural crop worldwide, with over 60 million tons of apples produced on more than 7 million hectares per year and are the focus of a large amount of research to improve their production efficiency and sustainability (Reyes et al., 2016). The popularity of apples is not only a result of their taste, but also of their high nutritional value and healthful properties (Dobrowolska-iwanek and Adamska, 2015). In Albania, apple is the most important fruit tree; there are about 3.7 million apple trees and producing over 70 thousand tons apple fruits. Although, commonly apple in Albania is cultivated in its south-east continental part, recently is also expanded in the western coastal plain of the country in order to benefit from the advantages of earliness and vicinity to the main markets (Domi et al., 2012).

Currently, the cultivation of apple grafted with dwarf rootstocks and close planting has become the trend and direction of the apple cultivation (Ding et al., 2017; Ma et al., 2013). They take up less room and can be planted close together to give good yields, the reduced size requires lower volumes of expensive pesticides and less labor for pruning and training, they produce fruit earlier and the size and color of the fruits are uniform, but the roots of dwarf apple trees are often not as well developed as in vigorous stock (Ma et al., 2013). Apart from internal factors like rootstock genotype and scion vigor, root growth is affected by soil temperature and soil moisture (Psarras et al., 2000) and irrigation practices (Tanasescu and Paltineanu, 2004). Since soil resources (water and nutrients) are unevenly distributed, or are subject to localized depletion the spatial deployment of the root system will in large determine the ability of grafted apple plants to exploit the available resources (Lynch, 1995). Hence, studying the development and the spatial distribution of root systems in dwarfing rootstocks, as well as an understanding of the relationship between the development of roots and shoots is of great significance for apple production (Ma et al., 2013).

Fine roots are the main components of the root system through which plants absorb water and nutrients. These relatively thin roots, with a high specific root length (length: dry weight ratio), form the younger parts of the root system (De Silva et al., 1999) and represent the most active and dynamic part of the root system, responsible for most water and nutrient uptake in plants. Given that fine roots are continually emerging, aging, and dying throughout the growing season, the composition of the fine fraction of root systems is very heterogeneous, with roots of different ages, lengths, diameters, colors, branching orders and degrees of mycorrhizal colonization (Artacho and Bonomelli, 2016). Although there are 
evidences to suggest that within this single size class of roots exist differences in form and function, in most studies all roots less than 1 or $2 \mathrm{~mm}$ in diameter are treated as a single class of structurally and physiologically identical individuals (McCormack et al., 2015; Wells et al., 2001).

Although grafting is an important method of propagation in several horticulture plants, the mechanism through which the scion affects the absorption capacity of rootstock remains poorly understood (Shu et al., 2017). While there are many publications regarding the effects of different rootstocks on the vegetative growth, yield and fruit quality of scions, there are few published reports on effects of scion cultivar on the rooting pattern of rootstock (Franco et al., 1995). Root behavior is largely unknown and research in this regard is surprisingly limited (Hunter et al., 2016), because it is easy to observe and record the growth and behavior of the aerial parts of a tree, but most difficult to make similar observations upon the root system (Swarbrick, 1930).

Considering, the limited information regarding the effects of the scion (cultivars) on the rootstock growth, and the practical importance of this information regarding proper spacing and proper crop management practices in intensive apple orchards, the aim of this study was to evaluate how could different apple cultivars used as scion in graft combination with the dwarfing rootstock M9 affects its root morphology and, as well, how its root morphology change in the course of years, under common commercial production conditions.

\section{Materials and Methods}

The study was conducted in a commercial apple orchard located in Dushk $\left(41.0005^{\circ} \mathrm{N}\right.$, $19.6848^{\circ} \mathrm{E}$ ), district of Lushnja, Albania, during the year 2015. The average air temperature of this site ranges from $5{ }^{\circ} \mathrm{C}$ to $25{ }^{\circ} \mathrm{C}$. Winters are cool and wet with mean temperatures in December and January respectively $11.8{ }^{\circ} \mathrm{C}$ and $9.8^{\circ} \mathrm{C}$. The lowest air temperatures recorded are in the range from $-1.5{ }^{\circ} \mathrm{C}$ to $-7{ }^{\circ} \mathrm{C}$ (in January and February). However, the incidence of frost is very low. Summers have a mean temperature of $26{ }^{\circ} \mathrm{C}$ and mean humidity of $60 \%$. The maximum air temperatures recorded are in June and July, up to $42^{\circ} \mathrm{C}$. Meanwhile the maximum winter air temperature recorded, range from $17{ }^{\circ} \mathrm{C}$ up to $24{ }^{\circ} \mathrm{C}$. The highest soil temperatures are recorded in June, July and August. They range from about $23{ }^{\circ} \mathrm{C}$ up to about $31{ }^{\circ} \mathrm{C}$. The lowest soil temperatures are recorded in January; the lowest ones recorded $6.7{ }^{\circ} \mathrm{C}$. The soil temperature (at $10 \mathrm{~cm}$ depth) exceeds $10{ }^{\circ} \mathrm{C}$ in the middle of March. The area is under a xeric regime with relatively dry and hot summers. Average annual rainfall of this zone is $900-1400 \mathrm{~mm}$, and more than $80 \%$ occurs during the rainy season from October to March. Therefore, irrigation is crucial for high agricultural production. The numbers of hours of sunshine is very high in June, July and August. It is approximately 110 hour for each ten day, but these figures are much smaller in winter months, no more than 30 to 40 hour of sunshine for each ten day.

The soil of the experimental site is classified as fluvisol. Sand, silt and clay composition at the upper soil layer $(0-30 \mathrm{~cm})$ were respectively $28.8 \%, 38.4 \%$ and $32 \%$, and at the second $(30-60 \mathrm{~cm})$ layer, were respectively $21.6 \%, 40.4 \%$ and $38 \%$. 
The experiment engaged three different cultivars; 'Golden delicious', 'Gala' and 'Starking', each grafted on M9 dwarfing rootstock, all in the same commercial field plot. The planting distances were $3.8 \times 1.3 \mathrm{~m}$ and plants were trained as French vertical axe. Common commercial practices were equally applied to all plants. Drip irrigation was installed and usually four cycles of irrigation with high, non-specified, water volumes were applied each year based on 'rules of thumb'. Fourteen and nine (only for 'Golden delicious') years old plants were included in the experiment. For that purpose, five plants of each cultivar were randomly selected and observed from the start of vegetation until harvesting and several experimental data were successfully collected. The root morphology data itself were collected by the end of vegetation, in November 2015.

The trench profile method (var Noorddwijk et al., 2001) was chosen to study the morphology of root system. For that purpose a trench was excavated and a vertical plane perpendicular to the planting row was established. The vertical profile was extended up to $130 \mathrm{~cm}$ on both sides of tree trunk and reached the depth of $100 \mathrm{~cm}$. The entire vertical profile was divided into $8 \mathrm{~cm}$ x $10 \mathrm{~cm}$ grid cells by a metallic net and in each grid cell roots were exposed using a small knife to remove surrounding soil. The root intersect method was used to count the roots (Tardieu, 1988); a root intersects was considered any intersection of a root with the vertical plane under study. The number of root intersects were counted in each grid cell $\left(80 \mathrm{~cm}^{2}\right)$ divided into three classes; fine roots $(<2 \mathrm{~mm})$, medium-sized roots $(2-5 \mathrm{~mm})$, and coarse roots (>5 mm) (Ceccon, 2011).

The total root number and total number of each root category of the entire vertical profile $(260 \mathrm{~cm} \times 100 \mathrm{~cm})$ were individually analyzed. The density of roots was calculated for each graft combination at three specified depths $(0-40 \mathrm{~cm}, 40-80 \mathrm{~cm}$ and $80-120 \mathrm{~cm})$ for the entire profile length $\left(260 \mathrm{~cm}\right.$ ) and expressed as roots (total number) per $100 \mathrm{~cm}^{-2}$. In addition, in order to analyze the side distribution of root system, the respective cumulative number of fine roots $(<2 \mathrm{~mm})$ in three successive distances $(0-40,0-80$ and $80-120 \mathrm{~cm})$ from the base of tree trunk was counted and expressed as percentage versus the total fine roots of the entire vertical profile. Similarly, in order to analyze the in depth distribution of root system the cumulative number of fine roots $(<2 \mathrm{~mm})$ in four successive distances $(0-20,0-40,0-60$ and $60-90 \mathrm{~cm})$ from soil surface was as well, counted and expressed as percentage versus the total fine roots of the entire vertical profile. By the end of October 2015, the diameter of trunk was measured by a caliper, $10 \mathrm{~cm}$ above the grafting point and based on that the trunk cross sectional area (TCA, $\mathrm{cm}^{2}$ ) was calculated. In addition, in order to estimate the annual vegetative growth of each cultivar, the length $(\mathrm{cm})$ and diameter $(1 \mathrm{~cm}$ above the insertion point, $\mathrm{mm})$ of six randomly selected vegetative shoots were measured and recorded at each previously randomly selected tree (30 in total for each cultivar). Finally, the harvesting of fruits was conducted as fruits reached the maturity stage and the harvesting period and yield $\left(\mathrm{kg} \mathrm{tree}^{-1}\right)$ of each previously randomly selected tree were individually recorded. Following that, yield efficiency (YE, $\mathrm{kg} \mathrm{cm}^{-2}$ ) was calculated for each graft combination as the ratio of harvested yield per plant $\left(\mathrm{kg} \mathrm{tree}^{-1}\right)$ with respective TCA (Fioravanço et al., 2016).

Differences in root number and root density, percentage of fine roots at selected intervals versus their total, trunk cross sectional area, shoot length and diameter, and yield and yield 
efficiency were tested by one-way ANOVA, using the personal computer (PC) program SigmaPlot 13 (Systat Software Inc., San Jose, CA, USA). Each significant ANOVA result ( $p<$ $0.05)$ was followed by a Holm-Sidak test at $p<0.05$ as a post-hoc test to compare pair wise means within and among treatments. Values given throughout the text are means \pm SD.

\section{Results}

\subsection{The Vegetative Growth and Production of Different Apple Cultivars}

There were significant differences among apple cultivars grafted onto M9 rootstock regarding shoot growth parameters, either length or diameter, and yield. 'Starking' demonstrated the most vigorous annual growth. Its annual shoot length reached $68 \mathrm{~cm}$, versus $58 \mathrm{~cm}$ and $48 \mathrm{~cm}$, respectively reached by 'Gala' and 'Golden delicious'. Similarly, shoot diameter of 'Starking' achieved $9.1 \mathrm{~mm}$, while to 'Gala' and 'Golden delicious' it was respectively $7.1 \mathrm{~mm}$ and 6.8 $\mathrm{mm}$. The weakest annual shoot growth was recorded in 'Golden delicious', although its differences with 'Gala' were not statistically significant (Table 1). Despite weak annual shoot growth 'Golden delicious' has the largest trunk cross sectional area (TCA, $21.18 \mathrm{~cm}^{-2}$ ), followed by 'Starking' $\left(18.56 \mathrm{~cm}^{-2}\right)$, both at the same statistical group. 'Gala' recorded the lowest value of TCA $\left(12.23 \mathrm{~cm}^{-2}\right)$, significantly less than 'Golden delicious' and 'Starking'. Opposite to vegetative vigor, 'Starking' recorded the lowest yield, only $6.8 \mathrm{~kg}$ tree ${ }^{-1}$ and lowest yield efficiency $\left(0.38 \mathrm{~kg} \mathrm{~cm}^{-2}\right)$ (Table 1$)$. 'Golden delicious' recorded the highest yield $\left(26.2 \mathrm{~kg} \mathrm{tree}^{-1}\right)$ and as well the highest yield efficiency. Interestingly, although it shows significant difference with 'Gala' regarding yield (26.2 vs. $15 \mathrm{~kg}$ tree $\left.^{-1}\right)$ no significant differences were found between them regarding yield efficiency $\left(1.28 \mathrm{~kg} \mathrm{~cm}^{-2} \mathrm{vs} .1 .22 \mathrm{~kg}\right.$ $\mathrm{cm}^{-2}$ )(Table 1). Important to note, the harvesting time of 'Gala' was almost a month earlier than either 'Golden delicious', or 'Starking' (Table 1).

Table 1. Shoot growth fruit production parameters of 14 year old apple plants (respectively 'Golden delicious', 'Gala' and 'Starking' grafted onto M9 rootstock) under field conditions in Lushnja district, Albania

\begin{tabular}{lcccccc}
\hline & \multicolumn{2}{c}{ Vegetative growth parameters } & \multicolumn{2}{c}{ Fruit production parameters } \\
\cline { 2 - 7 } Cultivar & $\begin{array}{c}\text { TCA } \\
\left(\mathrm{cm}^{-2}\right)\end{array}$ & $\begin{array}{c}\text { Shoot } \\
\text { length } \\
(\mathrm{cm})\end{array}$ & $\begin{array}{l}\text { Shoot } \\
\text { diameter } \\
(\mathrm{mm})\end{array}$ & $\begin{array}{c}\text { Harvesting } \\
\text { period }\end{array}$ & $\begin{array}{c}\text { Yield } \\
\left(\mathrm{kgtre}^{-1}\right)\end{array}$ & $\begin{array}{c}\text { Yield } \\
\text { efficiency } \\
\left(\mathrm{kg} \mathrm{cm}^{-2}\right)\end{array}$ \\
\hline $\begin{array}{l}\text { Golden } \\
\text { delicious }\end{array}$ & $21.18 \pm 5.0 \mathrm{a}$ & $48 \pm 21 \mathrm{~b}$ & $6.8 \pm 1.4 \mathrm{~b}$ & Sept. 25 & $26.2 \pm 10.2 \mathrm{a}$ & $1.28 \pm 0.5 \mathrm{a}$ \\
Gala & $12.23 \pm 1.7 \mathrm{~b}$ & $58 \pm 20 \mathrm{ab}$ & $7.1 \pm 2.2 \mathrm{~b}$ & August 20 & $15.0 \pm 5.8 \mathrm{ab}$ & $1.22 \pm 0.4 \mathrm{a}$ \\
Starking & $18.56 \pm 3.9 \mathrm{a}$ & $68 \pm 22 \mathrm{a}$ & $9.1 \pm 2.5 \mathrm{a}$ & Sept. 25 & $6.8 \pm 2.4 \mathrm{~b}$ & $0.38 \pm 0.2 \mathrm{~b}$ \\
\hline Significance & 0.009 & 0.002 & 0.004 & & $<0.001$ & 0.005 \\
\hline
\end{tabular}

Different letters indicate significant differences within following parameters (Holm-Sidak test, $p<0.05$; mean $\pm \mathrm{SD}$ ). 
3.2 The Influence of Scion Cultivar and Plant Age on Growth and Spatial Distribution of Rootstock Roots

The growth of root system was significantly influenced from the cultivar used as a scion in a specific graft combination. 'Gala' and 'Starking' have shown a significantly higher number of roots thinner than $2 \mathrm{~mm}$ compared to 'Golden delicious' (Table 2). Since roots thinner than 2 $\mathrm{mm}$ represents a very large portion of the total number of roots (nearly $90 \%$ ), no doubt, both them have also a significantly higher total number of roots than 'Golden delicious' (Table 2). On the contrary, the picture regarding $2-5 \mathrm{~mm}$ and $>5 \mathrm{~mm}$ fractions was different. 'Gala' has the highest number of intermediate $(2-5 \mathrm{~mm})$ roots, followed by 'Golden delicious' with a slightly smaller number of such roots (Table 2). 'Starking' has the smallest number of 2-5 mm roots, significantly less than Gala, but statistically equall with 'Golden delicious'. Meanwhile 'Gala' has the smallest number of older, transport roots $(>5 \mathrm{~mm})$, significantly less than both 'Golden delicious' and 'Starking' (Table 2). Significant differences were also found between Golden delicious and Starking. The latest shows the highest number (21) of roots thicker than $5 \mathrm{~mm}$. The morphology of root system was also significantly influenced by the age of grafted apple plants. Comparing 9 and 14 years old of M9 x Golden delicious plants was clear that the total number of roots was significantly reduced in older ones (Table 3 ). The reduction was proportional with the total number of roots for two first root categories; <2mm (67\% less) and 2-5 $\mathrm{mm}(70 \%)$, but not regarding roots larger than $5 \mathrm{~mm}$.

Table 2. Root number and root density of 14 year old apple plants (respectively 'Golden delicious', 'Gala' and 'Starking' grafted onto M9 rootstock) under field conditions in Lushnja district, Albania

Number of roots

Root density (total root $100 \mathrm{~cm}^{-2}$ )

Cultivar

Root diameter $(\mathrm{mm}) \quad$ In depth soil layer $(\mathrm{cm})$

$\begin{array}{lrlrl}\text { r } 2-5 \quad>5 & \begin{array}{r}\text { Total } \\ \text { root }\end{array} & 0-40 & 40-80 & 80-120\end{array}$

\begin{tabular}{lccccccc}
$\begin{array}{l}\text { Golden } \\
\text { delicious }\end{array}$ & $280 \pm 26 \mathrm{~b}$ & $26 \pm 4 \mathrm{ab}$ & $17 \pm 3 \mathrm{~b}$ & $324 \pm 20 \mathrm{~b}$ & $1.25 \pm 0.05 \mathrm{c}$ & $1.00 \pm 0.01 \mathrm{c}$ & $0.95 \pm 0.03$ \\
Gala & $342 \pm 20 \mathrm{a}$ & $29 \pm 4 \mathrm{a}$ & $11 \pm 2 \mathrm{c}$ & $382 \pm 21 \mathrm{a}$ & $1.51 \pm 0.02 \mathrm{~b}$ & $1.15 \pm 0.01 \mathrm{~b}$ & $1.04 \pm 0.08$ \\
Starking & $340 \pm 17 \mathrm{a}$ & $22 \pm 3 \mathrm{~b}$ & $21 \pm 3 \mathrm{a}$ & $383 \pm 20 \mathrm{a}$ & $1.63 \pm 0.09 \mathrm{a}$ & $1.34 \pm 0.08 \mathrm{a}$ & $0.96 \pm 0.06$ \\
\hline Significance & $<0.001$ & 0.004 & $<0.001$ & $<0.001$ & $<0.001$ & $<0.001$ & 0.118 \\
\hline
\end{tabular}

Different letters indicate significant differences within following parameters (Holm-Sidak test, $p<0.05$; mean $\pm \mathrm{SD}$ ). 
Table 3. Root number of 9 year old and 14 year old apple plants (cv. Golden delicious grafted onto M9 rootstock) under field conditions in Lushnja district, Albania

\begin{tabular}{lcccr}
\hline & \multicolumn{3}{c}{ Number of roots } \\
\cline { 2 - 5 } Plant age & $<2 \mathrm{~mm}$ & $2-5 \mathrm{~mm}$ & $>5 \mathrm{~mm}$ & Total \\
\hline $9 \mathrm{yr}$ & $417 \pm 16 \mathrm{a}$ & $37 \pm 5 \mathrm{a}$ & $28 \pm 3 \mathrm{a}$ & $482 \pm 56 \mathrm{a}$ \\
$14 \mathrm{yr}$ & $280 \pm 26 \mathrm{~b}$ & $26 \pm 4 \mathrm{~b}$ & $17 \pm 3 \mathrm{~b}$ & $324 \pm 20 \mathrm{~b}$ \\
\hline Significance & $<0.001$ & 0.004 & $<0.001$ & $<0.001$ \\
\hline
\end{tabular}

Different letters indicate significant differences within following parameters (Holm-Sidak test, $p<0.05$; mean \pm SD).

The pattern of fine root distribution in grafted apple trees was significantly influenced by individual scion characteristics. 'Starking' was more capable to keep the bulk of roots closer to the trunk by maintaining nearly to $40 \%$ of its total fine roots in the distance up to $40 \mathrm{~cm}$ far from the trunk (Figure 1A). The percentage of fine roots found in this distance for 'Golden delicious' (37\%) was significantly less than 'Starking', while no significant difference was found between 'Starking' and 'Gala' (38\%). This capability of 'Starking' becomes more evident counting the percentage of fine roots found in the distance up to $80 \mathrm{~cm}$ from the base of trunk (71\%), this time statistically significant versus both; 'Golden delicious' $(66 \%)$ and 'Gala'(67\%) (Figure 1B). Contrary to above, 'Starking' has the smallest portion of total roots situated in the distance 80-120 cm (24\%). Both, 'Golden delicious' (30\%) and 'Gala' (28\%) did have significantly higher portions of their roots moved away from the trunk (Figure 1C). Interesting to note, significant differences did also exist between 'Golden delicious' and 'Gala'.

The individual characteristics of scion did also have significant effects on the in depth distribution of the rootstock roots. 'Starking' recorded the highest root density in $0-40 \mathrm{~cm}$ and 40-80 cm depth (respectively 1.63 and 1.34 roots per $100 \mathrm{~cm}^{-2}$ ), significantly higher than 'Gala' (respectively 1.51 and 1.15 roots per $100 \mathrm{~cm}^{-2}$ ) and 'Golden delicious' (respectively 1.25 and 1.0 roots per $100 \mathrm{~cm}^{-2}$ ). Significant differences did also exist between 'Gala' and 'Golden delicious' at the same soil depth, but no significant differences were found among cultivars at 80-120 cm soil depth (Table 2). 

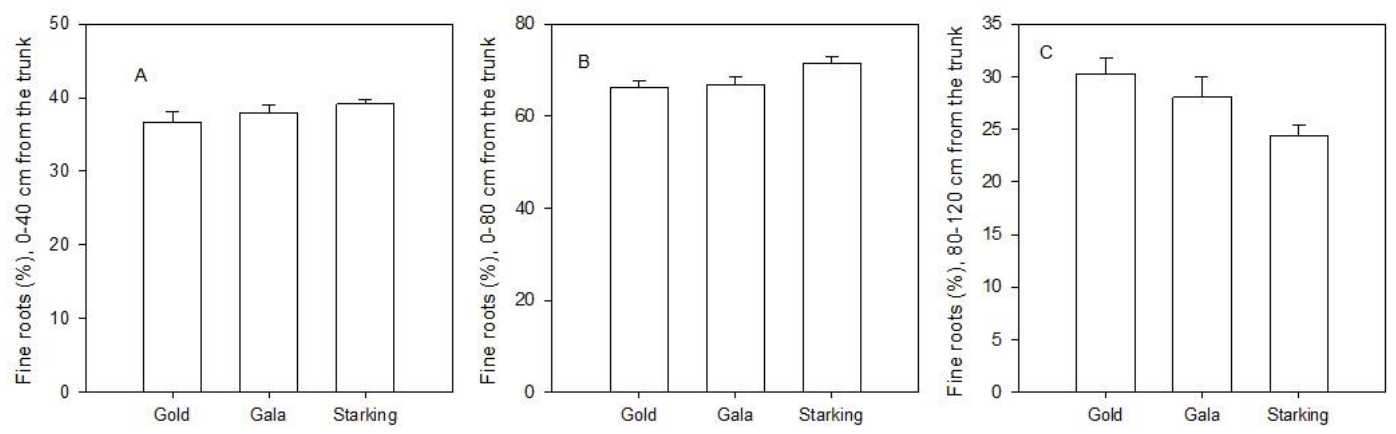

Figure 1. The number of fine roots of M9 rootstock (percentage over total number of fine roots), at different by side distances $(0-40,0-80$ and $80-120 \mathrm{~cm})$ from the base of trunk, grafted with different apple cultivars (Golden Delicious, Gala and Starking)

'Starking' provided the largest portion of fine root numbers down to 20, 40 and $60 \mathrm{~cm}$ deep; respectively $26 \%, 60 \%$ and $84 \%$. The differences were significant versus both, 'Gala' and 'Golden delicious' at each analyzed depth. The lowest presence of fine roots in the upper layers of the soil $(20,40$ and $60 \mathrm{~cm})$ was found in 'Golden delicious' plants. There were only $12 \%$ of its total fine roots found up to $20 \mathrm{~cm}$ depth, $47 \%$ up to $40 \mathrm{~cm}$ depth and $73 \%$ up to 60 cm depth (Figures 2A, 2B, 2C), much less than either 'Starking' or 'Gala'. Contrary to the above soil layers, 'Starking' had the smallest percentage of fine roots in the deeper soil layers $(60-90 \mathrm{~cm})$, only $24 \%$, significantly less than both, 'Gala' $(28 \%)$ and 'Golden delicious' (30\%). The differences between 'Gala' and 'Golden delicious' were also statistically significant (Figure 2D).

The spatial distribution of fine roots was significantly affected by the age of grafted plants. The effects were expressed either in the side distribution of roots, or in depth. Owing to ageing, the bulk of roots in M9 x Golden delicious grafted plants were gradually moved away from the trunk of plant. Indeed, compared to nearly 55\% in 9 year old plants, only nearly $35 \%$ of the fine roots were found within the distance of up to $40 \mathrm{~cm}$ from the trunk in 14 year old plants (Figure 3A). Similarly, while nearly $80 \%$ of roots in 9 year old plants were found within the distance of $80 \mathrm{~cm}$ far from the trunk, only nearly $60 \%$ of them were found in 14 year old plants (Figure 3B). Nearly $30 \%$ of total fine root number in 14 year old plants were situated in the belt lays between 80 and $120 \mathrm{~cm}$ far from the trunk, while much less (only 15\%) were found to the same distances for 9 year old plants (Figure 3C). 

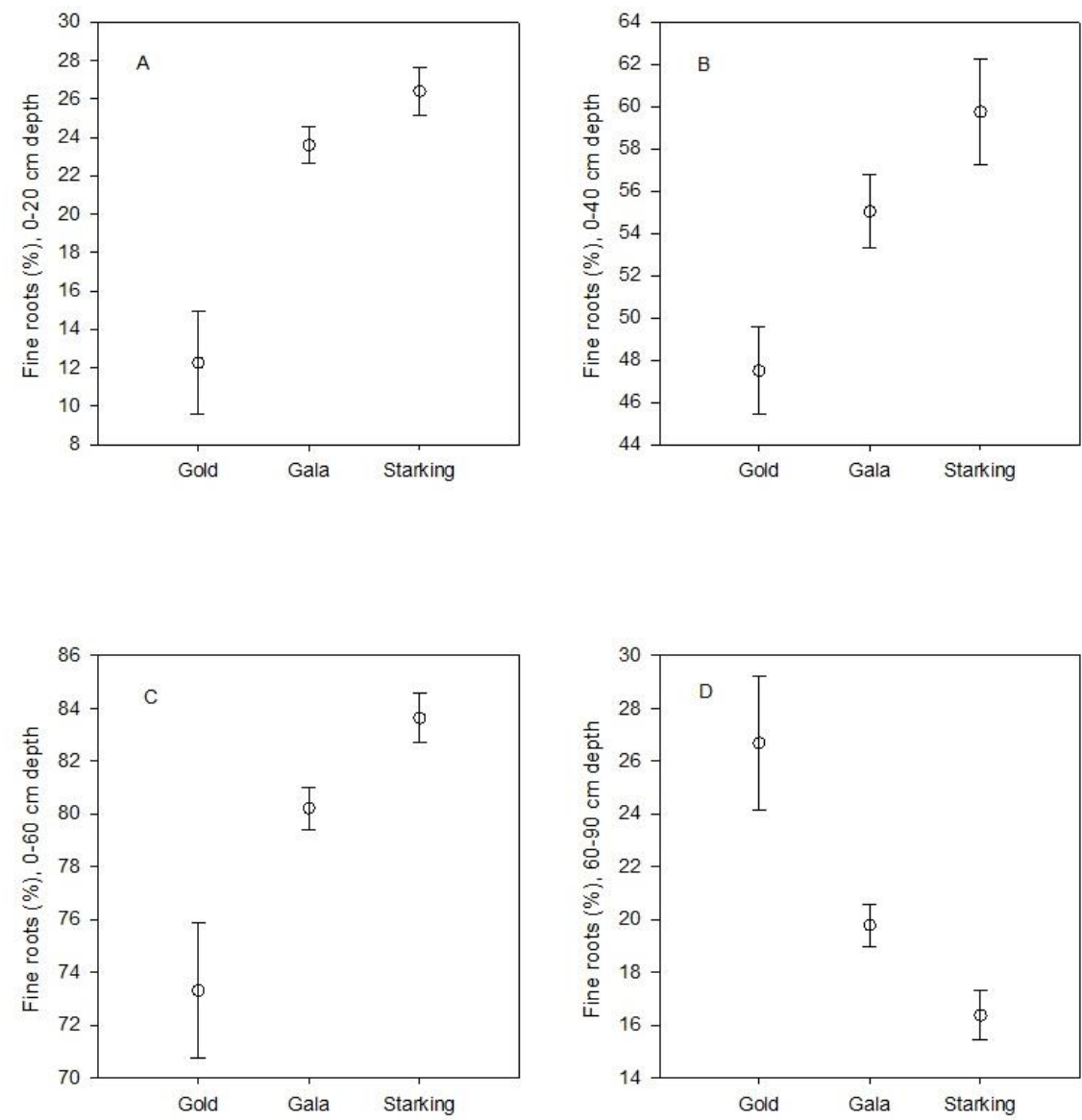

Figure 2. The number of fine roots of M9 rootstock (percentage over total number of fine roots), at different in depth distances $(0-20,0-40,0-60$ and 60-90 cm) from soil surface, grafted with different apple cultivars (Golden Delicious, Gala and Starking)
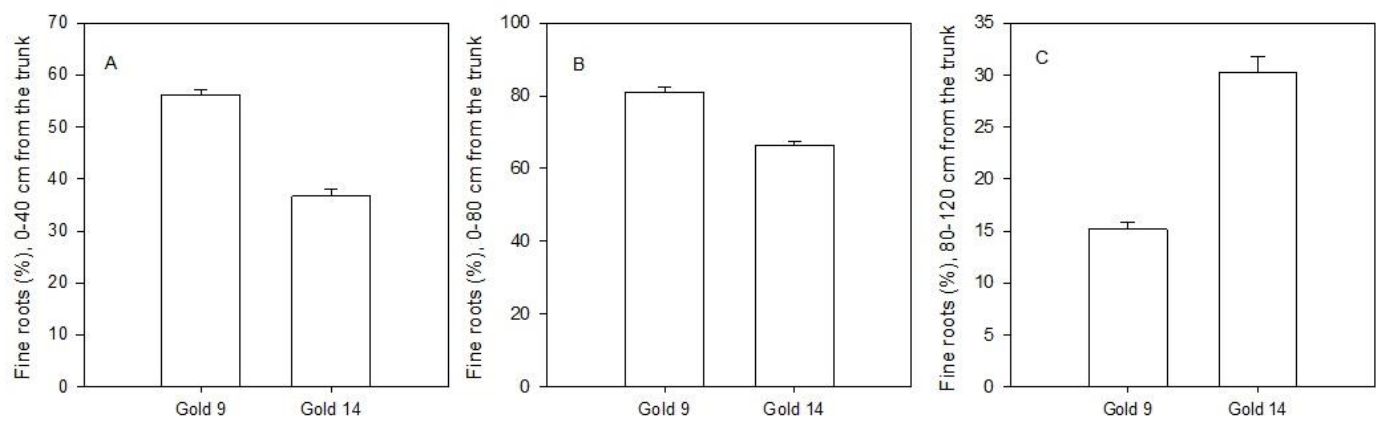

Figure 3. The number of fine roots of M9 rootstock (percentage over total number of fine roots), at different side distances $(0-40,0-80$ and $80-120 \mathrm{~cm})$ from the base of trunk, grafted with

Golden Delicious apple cultivar, respectively 9 and 14 years after transplanting

The plant age has also significantly affected the in depth distribution of roots. As plants getting older, the bulk of roots of the rootstock were gradually moving into deeper layers of the soil. As it can easily see from Figure 4 , in the younger plants ( 9 year old) the majority of 


\section{Macrothink}

roots was situated in the upper layers of the soil. Respectively nearly $25 \%$ and nearly $60 \%$ of fine roots in 9 year old plants were found in depths up to $20 \mathrm{~cm}$ and up to $40 \mathrm{~cm}$. The difference with the respective proportions of 14 year old plants was significant and quite large; respectively nearly $12 \%$ and nearly 45\% (Figures 4A, 4B). The advantage of 9 year old versus 14 year old plants remains statistically significant until $60 \mathrm{~cm}$ deep (Figure 4C), but the difference between them is getting smaller (nearly $80 \%$ vs., nearly $74 \%$ ). On the contrary, a significantly higher percentage of fine root number was found in depth between 60 and $90 \mathrm{~cm}$ in 14 year old plants (nearly 27\%), compared to nearly $21 \%$ in 9 year old plants (Figure 4D).
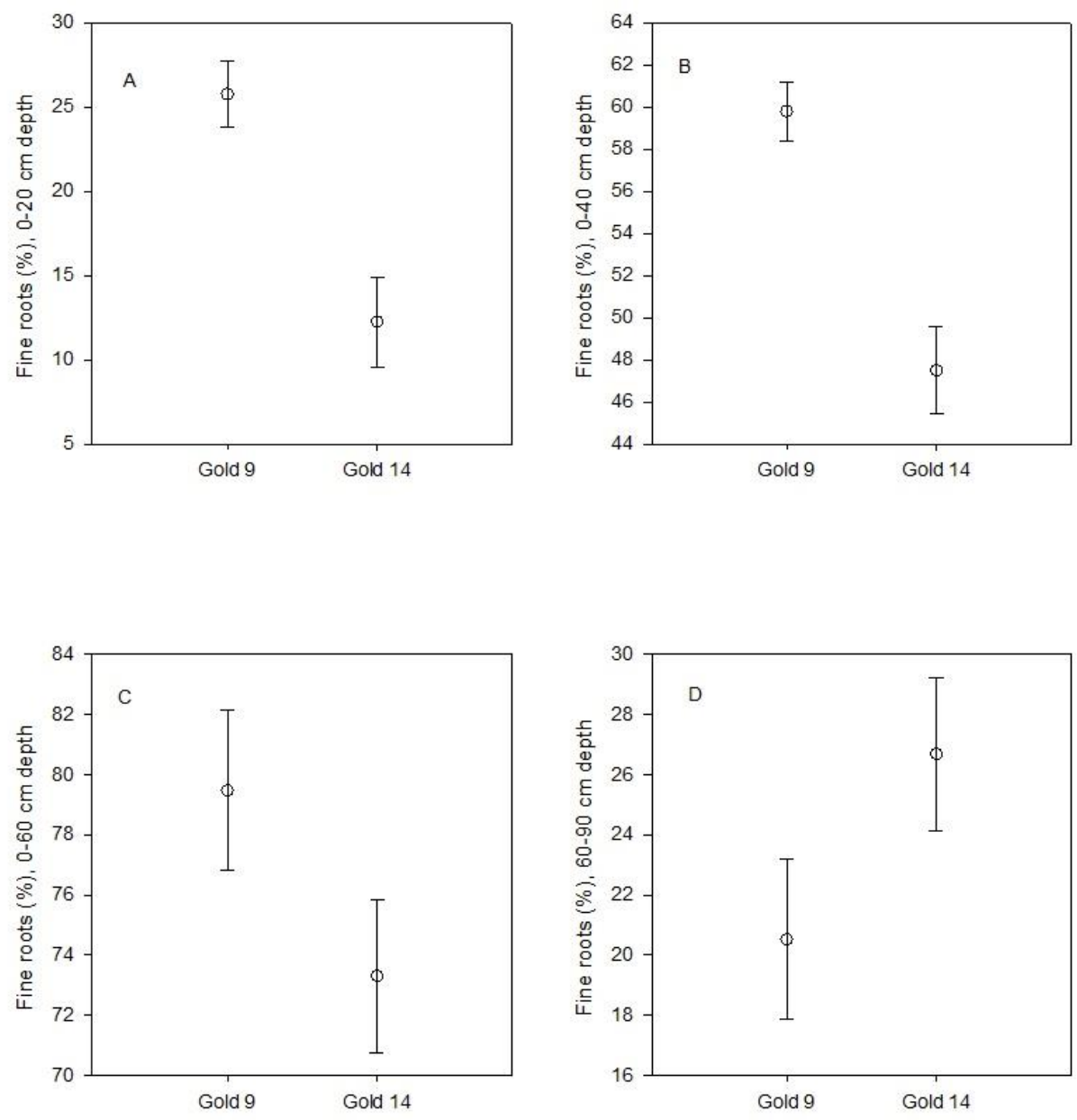

Figure 4. The number of fine roots of M9 rootstock (percentage over total number of fine roots), at different in depth distances (0-20, 0-40, 0--60 and 60-90 cm) from soil surface, grafted with Golden Delicious apple cultivar, respectively 9 and 14 years after transplanting

\section{Discussions}

Since fine roots have an increased mycorrhizal colonization rate, and are largely marked as the primarily absorptive roots (McCormack et al., 2015; Paltineanu et al., 2016), our discussion is based on the number and spatial distribution of this category. As a matter of fact, root and shoot growth in apple is asynchronous reflecting this way the competition for 
carbohydrates between aboveground and belowground organs (Eissenstat et al., 2001; Franco et al., 1995) and the period of active root growth extended beyond that of aboveground vegetative growth. It begins before the leaves unfolded and continuing after shoot growth ceased. As already proved (Eissenstat et al., 2001; Abrisqueta et al., 2017), root growth of apple rootstocks increased once harvesting was completed and the canopy was big enough to distribute the required photo assimilates to organs that would ensure a successful yield the following season.

Apparently, this happen because different organs, compete among each other for assimilate (Goyal and Bishnoi, 2017). According to Kramer and Kozolowski (1979) (after Abrisqueta et $a l ., 2017)$ the differential sink capacities of the different organs depends on the organ activity and distance from the carbohydrate source and follow the following hierarchy: fruits $>$ young leaves and stem tips $>$ mature leaves $>$ cambium $>$ roots $>$ storage tissues. Being the organ with the highest sink capacity (Abramoff and Finzi, 2015; Artacho and Bonomelli, 2016; Ding et al., 2017), fruit load determines the growth rate of other vegetative or storage organs. Hence, since the differences regarding the yield among cultivars included in our experiment were significant, significant differences regarding the growth rate of either shoots or roots were logically expected. Indeed, 'Starking' with the lowest fruit yield (only $6.8 \mathrm{~kg}$ tree ${ }^{-1}$ ) had the longest and the thickest shoots, and as well, the highest number of thin $(<2 \mathrm{~mm})$ roots.

Heavy fruit production in apple tree has been associated with high root mortality (Eissenstat et al., 2001), and we also assume that is a reason why 'Golden delicious' have the lowest number of thin $(<2 \mathrm{~mm})$ roots. In addition, the number of roots was been related with the time of fruit maturity (Artacho and Bonomelli, 2016); a decrease in root production was observed due to the presence of growing fruits in late-maturing cultivars (Abrisqueta et al., 2017). Similarly, we found that although there were no significant differences regarding yield efficiency (YE, $\mathrm{kg} \mathrm{cm}^{-2}$ ) between 'Golden delicious' and 'Gala' the differences regarding the number of roots less than $2 \mathrm{~mm}$ and the total number of roots were significantly different. Being harvested almost one month earlier allows 'Gala' to supply roots with larger amounts of assimilates and hence achieving in the upper layer of the soil $(0-40$ and $40-80 \mathrm{~cm}) \mathrm{a}$ significantly higher root density than 'Golden delicious'.

Similar to very early report of Swarbrick (1930) and recent ones of Zhu et al., (1999), Psarras et al., (2000) and Harrison et al., (2016) we found that root morphology of M9 dwarfing rootstock was significantly affected by scion vigour. 'Starking' did not only have the largest number of fine roots; as well it was capable to keep the bulk of its roots closer to the base of tree trunk. Practically, nearly $70 \%$ of less than $2 \mathrm{~mm}$ roots in M9xStarking graft combination was found in the distance of up to $80 \mathrm{~cm}$ far from the trunk. The differences with 'Gala' and 'Golden delicious' were statistically significant, indicating a higher root regeneration rate by 'Starking', a conclusion supported by findings of Fernandez et. al (2014) whose have found positive correlations between the vigor of scion and root number. Having fewer carbohydrates addressed towards the root system, due to higher YE, M9xGolden delicious and M9xGala were less capable to maintain their root system close to the trunk. As the result, their bulk of absorptive roots were gradually shifted further away from the base of trunk. A considerable number of fine roots were found further than $80 \mathrm{~cm}$ far from the trunk in 
M9xGolden delicious and M9xGala (respectively 30\% and 28\%) and as a consequence, an increased competition for water and nutrient elements is expected among the trees in the row . A similar concern is raised by Paltineanu et al., (2016) in apple and plum tree.

Our results proved that there were significant effects of scion on the in depth root distribution, too. Indeed, being capable to produce higher amounts of assimilates due to its larger above ground biomass and addressing a larger portion of them to the root system due to limited fruit load, 'Starking' was capable to maintain the bulk of its absorptive roots in the upper, more fertile, soil layers.

There are evidences that the phenology of root system is affected by the age of tree (Wu et al., 2012). Studying young (1-3 yrs after transplanting) trees Watson et al., (2006) found a decreasing root length into deeper soil layers. However, referring to previous publications (Hughes and Gandar, 1993) they admitted that the soil volume occupied by the root system reaches its maximum at 4 years old plants and that a more uniform root distribution exists to older (4-14 year old) apple trees. Ma et al., (2013) also reports that in very young orchards, the root distributions are bowl-shaped, with the roots centered near the stem, whereas older trees have a more layered structure with a higher root density further away from the trunk. Our results confirm these findings. By studying the patterns of root distribution in 9 and 14 year old M9xGolden delicious plants, we found the bulk of absorptive roots in older plants was shifted further away from the base of trunk and had gone deeper into the soil. That was different from what Bouillet et al., (2002) have reported in forest tree. We assume the differences are caused by quite different crop management practices. While the forest trees exploit the gradually increased concentration of nutrients in the top soil layers due to the decomposition of the forest floor (Bouillet et al., 2002), the apple trees have been subject of frequent soil tillage, which periodically have pruned off the roots scattered in the upper layers of the soil, and intensive irrigations which drain the nutrient elements into deeper soil layers.

\section{Conclusions}

It is clear that the tested apple cultivars have a quite distinctive performance. Considering yield efficiency $\left(\mathrm{kg} \mathrm{cm}^{-2}\right)$ as an important index of orchard productivity we should say that because of very low index $\left(0.38 \mathrm{~kg} \mathrm{~cm}^{-2}\right), \mathrm{M} 9 \mathrm{x}$ 'Starking' combination is not appropriate in that specific area. Although 'Golden delicious' and 'Gala' have statistically equal yield efficiency indexes, one should consider that the latest is less vegetative and occupies a smaller volume. Because of that, it might be planted in higher densities to achieve higher orchard productivity. The right planting distances needs to be experimented, considering also light penetration and the mechanization of orchard.

The pattern of root distribution is highly influenced by scion vigor and productivity. Being the less productive cultivar in that specific area, 'Staking' was been able to construct the most vigor root system and maintain it closer to the trunk. Although 'Golden delicious' and 'Gala' have similar vegetative vigor and productivity indexes, due to earlier maturity the latest was been capable to maintain a higher root density in the upper, more fertile soil layers, and as well, closer to tree trunk. 
The specific characteristics of each cultivar should be considered during irrigation and fertilization to better fit the distance of drip lines from the trunk and the distance between the emitters, as well as the irrigation frequency and volume with the horizontal and in depth root distribution of each specific cultivar.

The pattern of root distribution was changing over years. The plants tents to shift the bulk of absorptive roots further from the tank, risking to bring them closer to the next fruit tree and increase the in row competition among apple trees. Simultaneously, roots go deeper, into less fertile soil layers. This tendency was more visible to high yielding and late maturity cultivars. Due to that, the irrigation and fertilization practices should be adapted to changes of root distribution in the course of plant life cycle. It would be wise considering the increase of water volumes at every irrigation cycle in older orchards.

\section{References}

Abramoff, R. Z., \& Finzi, A. C. (2015). Are above- and below-ground phenology in sync? New Phytologist, 205(3), 1054-1061. https://doi.org/10.1111/nph.13111

Abrisqueta, I., Conejero, W., López-Martínez, L., Vera, J., \& Ruiz-Sánchez, M. C. (2017). Root and aerial growth in early-maturing peach trees under two crop load treatments. Spanish Journal of Agricultural Research, 15(2). https://doi.org/10.5424/sjar/2017152-10714

Artacho, P., \& Bonomelli, C. (2016). Changes in fine-root production, phenology and spatial distribution in response to $\mathrm{N}$ application in irrigated sweet cherry trees. Tree Physiology, 36(5), 601-617. https://doi.org/10.1093/treephys/tpw002

Bouillet, J. P., Laclau, J. P., Arnaud, M., M'Bou, A. T., Saint-André, L., \& Jourdan, C. (2002). Changes with age in the spatial distribution of roots of Eucalyptus clone in Congo impact on water and nutrient uptake. Forest Ecology and Management, 171(1-2), 43-57. https://doi.org/10.1016/S0378-1127(02)00460-7

Ceccon, C. (2011). Influence of nitrogen and soil physical characteristics on belowground carbon flux dynamics of woody plants. Retrieved from http://amsdottorato.cib.unibo.it/3982/

de Silva, H. N., Hall, A. J., Tustin, D. S., \& Gandar, P. W. (1999). Analysis of Distribution of Root Length Density of Apple Trees on Different Dwarfing Rootstocks. Annals of Botany, 83(4), 335-345, https://doi.org/10.1006/anbo.1999.0829

Ding, N., Chen, Q., Zhu, Z., Peng, L., Ge, S., \& Jiang, Y. (2017). Effects of crop load on distribution and utilization of $13 \mathrm{C}$ and $15 \mathrm{~N}$ and fruit quality for dwarf apple trees. Scientific Reports, 7(1), 14172. https://doi.org/10.1038/s41598-017-14509-3

Dobrowolska-iwanek, J., \& Adamska, A. (2015). Traditional versus modern apple cultivars-a comparison of juice composition, Folia Hort. 27(1), 33-41.

https://doi.org/10.1515/fhort-2015-0012

Domi, H., Spahiu, T., Kullaj, E., \& Thomaj, F. (2012). Rootstock influence on apple canopy architecture under high radiation and temperature. Agroznanje, 13, 527-533. https://doi.org/10.7251/AGREN1204527D 
Eissenstat, D. M., Wells, C. E., Wang, L., \& Wang, L. (2001). Root efficiency and mineral nutrition in apple. Acta Horticulturae, 564, 165-183.

https://doi.org/10.17660/ActaHortic.2001.564.19

Fernandez, Rodney Thomas, Fernandez, R Thomas, \& Perry, R.L. (2014). Root Distribution Patterns of Nine Apple Rootstock in Two Contrasting Soil Root Distribution Patterns of Nine Apple Rootstock in Two Contrasting Soil Types. J. Amer. Soc. Hort. Sci. 120(1), 6-13. https://doi.org/10.21273/JASHS.120.1.6

Fioravanço, J. B.C., Beatriz, A., Czermainski, C., Ricardo, P., \& Oliveira, D. (2016). Yield efficiency for nine apple cultivars grafted on two rootstocks. Ciência Rural, 46(10),1701-1706. https://doi.org/10.1590/0103-8478cr20141754

Franco, J. A., Abrisqueta, J. M., \& Hernansaez, A. (1995). Root development of almond rootstocks in a young almond orchard under trickle irrigation as affected by almond scion cultivar. Journal of Horticultural Science, 70(4), 597-607. https://doi.org/10.1080/14620316.1995.11515332

Goyal, R. K., \& Bishnoi, C. (2017). Assimilate partitioning and distribution in fruit crops : A review. Journal of Pharmacognosy and Phytochemistry, 6(3), 479-484.

Harrison, N., Barber-Perez, N., Pennington, B., Cascant-Lopez, E., \& Gregory, P. J. (2016). Root system architecture in reciprocal grafts of apple rootstock-scion combinations. Acta Horticulturae, 1130, 409-414. https://doi.org/10.17660/ActaHortic.2016.1130.61

Hughes, K., \& Gandar, P. W., (1993). Length densities, occupancies, and masses of apple root systems. Plant and Soil, 148, 211-221. https://doi.org/10.1007/BF00012859

Hunter, J. J., Archer, E., Van Schalkwyk, D., Strever, A. E., \& Volschenk, C. G. (2016). Grapevine roots: Interaction with natural factors and agronomic practices. Acta Horticulturae, 1136, 63-80. https://doi.org/10.17660/ActaHortic.2016.1136.10

Lynch, J. (1995). Root Architecture and Plant Productivity. Plant Physiology, (1995), 7-13. https://doi.org/10.1104/pp.109.1.7

Ma, L., Hou, C. W., Zhang, X.-Z., Lian, H.-L., Han, D. G., Wang, Y., \& Han, Z.-H. (2013). Seasonal Growth and Spatial Distribution of Apple Tree Roots on Different Rootstocks or Interstems. Journal of the American Society For Horticultural Science, 138(2), 79-87. https://doi.org/10.21273/JASHS.138.2.79

McCormack, M. L., Dickie, I. A., Eissenstat, D. M., Fahey, T. J., \& Fernandez, C. W., Guo, D., ... Zadworny, M. (2015). Redefining fine roots improves understanding of below-ground contributions to terrestrial biosphere processes. New Phytologist, 207, 505-518. https://doi.org/10.1111/nph.13363

Palmer, J. W., Wünsche, J. N., Meland, M., \& Hann, A. (2002) Annual dry-matter production by three apple cultivars at four within-row spacings in New Zealand. The Journal of Horticultural Science and Biotechnology, 77, 712-717, https://doi.org/ 10.1080/14620316.2002.11511561 
Paltineanu, C., Nicolae, S., Tanasescu, N., Chitu, E., \& Ancu, S. (2016). Investigating Root Density of Plum and Apple Trees Grafted on Low-Vigor Rootstocks to Improve Orchard Management. Erwerbs-Obstbau. https://doi.org/10.1007/s10341-016-0293-7

Psarras, G., Merwin, I.A., Lakso, A.N., \& Ray, J.A. (2000). Root Growth Phenology , Root Longevity, and Rhizosphere Respiration of Field Grown ' Mutsu 'Apple Trees on 'Malling 9' Rootstock. J. Amer. Soc. Hort. Sci. 125(5), 596-602. https://doi.org/10.21273/JASHS.125.5.596

Reyes, F., DeJong, T., Franceschi, P., Tagliavini, M., \& Gianelle, D. (2016). Maximum Growth Potential and Periods of Resource Limitation in Apple Tree. Frontiers in Plant Science, 7, 1-12. https://doi.org/10.3389/fpls.2016.00233

Shu, B., Liu, L., Jue, D., Wang, Y., Wei, Y., \& Shi, Sh. (2017) Effects of avocado (Persea americana Mill.) scion on arbuscular mycorrhizal and root hair development in rootstock. Archives of Agronomy and Soil Science, 63, 1951-1962. https://doi.org/10.1080/03650340.2017.1317921

Swarbrick, T. (1930). Rootstock and Scion Relationship.: Some Effects of Scion Variety upon the Rootstock. Journal of Pomology and Horticultural Science, 8, 210-228. https://doi.org/10.1080/03683621.1930.11513361

Tanasescu, N., \& Paltineanu, C. (2004). Root distribution of apple tree under various irrigation systems within the hilly region of Romania. Int. Agrophysics, 18, 175-180.

Tardieu, F., (1988). Analysis of the spatial variability of maize root density. I. Effect of wheel compaction on the spatial arrangement of roots. Plant Soil 107, 259-266. https://doi.org/10.1007/BF02370555

van Noordwijk, M., Brouwer, G., Meijboom, F., do Rosário, G., Oliveira, M., \& Bengough, A. G. (2001). Trench Profile Techniques and Core Break Methods. In: Smit A.L., Bengough A.G., Engels C., van Noordwijk M., Pellerin S., van de Geijn S.C. (eds) Root Methods. Springer, Berlin, Heidelberg. https://doi.org/10.1007/978-3-662-04188-8_7

Watson, T. W., Appel, N. D., Arnold, A. M., Kenerley, M. C., Watson, T. W., Appel, N. D., ... Kenerley, M. C. (2006). Spatial distribution of Malus root systems in irrigated, trellised orchards. The Journal of Horticultural Science and Biotechnology, 81, 745-753. https://doi.org/10.1080/14620316.2006.11512132

Wells, C. E., Eissenstat, D. M., Ecology, S., \& Mar, N. (2001). Marked Differences in Survivorship among Apple Roots of Different Diameters. Ecology, 82, 882-892. https://doi.org/10.1890/0012-9658(2001)082[0882:MDISAA]2.0.CO;2

Wu, T., Wang, Y., Yu, C., Chiarawipa, R., Zhang, X., Han, Z., \& Wu, L. (2012). Carbon sequestration by fruit trees - Chinese apple orchards as an example. PLoS ONE, 7(6), 1-13. https://doi.org/10.1371/journal.pone.0038883

Zhu, L. H., Welander, M., \& Hellgren, O. (1999). Growth rates and biomass production of micropropagated apple plants of M26 and Gravenstein on their own roots and in different 
micrografted combinations under non-limiting and limiting nutrient conditions. Journal of Experimental Botany, 50(336), 1189-1198. https://doi.org/10.1093/jxb/50.336.1189

\section{Copyright Disclaimer}

Copyright for this article is retained by the author(s), with first publication rights granted to the journal.

This is an open-access article distributed under the terms and conditions of the Creative Commons Attribution license (http://creativecommons.org/licenses/by/4.0/). 